\title{
Brand Attachment on Service Loyalty in Banking Sector
}

\author{
Mohammad Javad Taghipourian ${ }^{1} \&$ Mahsa Mashayekh Bakhsh ${ }^{2}$ \\ ${ }^{1}$ Departmental of management, Islamic Azad University, Chalous branch, Iran \\ ${ }^{2}$ Departmental of Business Management, Islamic Azad University, Babol branch, Iran \\ Correspondence: Mahsa Mashayekh Bakhsh, Departmental of Business Management, Islamic Azad University, \\ Babol branch, Iran. Tel: 98-936-192-2999. E-mail: m.mashayekhbakhshi@gmail.com
}

\author{
Received: August 16, 2016 Accepted: September 13, 2016 Online Published: September 22, 2016 \\ doi:10.5539/ijms.v8n5p146 URL: http://dx.doi.org/10.5539/ijms.v8n5p146
}

\begin{abstract}
The purpose of this study is to examine the effects of brand attachment on service loyalty to the services provided by financial sector. As one of the extremely valuable assets of every firm is its brand, attachment creates a deep emotional link between the consumers and the brand such that it contributes to the success of brand management process. To this end, the effects of two dimensions of the construct (brand-self connection and brand prominence) on each of the dimensions of service loyalty would be explored. The questionnaire is based on Park et al. (2010) and Sudhahar et al. (2006). The results of structural equations modeling indicated that brand attachment had a significant positive effect on service loyalty. Furthermore, the existed a positive effect on the dimensions of brand attachment-i.e., brand-self connection and brand prominence- and all dimensions of loyalty-i.e., behavioral, attitudinal, cognitive, conative, affective, commitment, and trust). Among them, brand-self connection had the highest effect on cognitive loyalty, trust-based loyalty, and commitment-based loyalty while brand prominence was most effective on affective loyalty, cognitive loyalty, and trust-based loyalty.Because of the increase in the number of institutions in banking sector and the diversity of services they offer, banking managers can take the advantage of using the results of brand attachment's effect on the study variables and enhance the loyalty to their services.
\end{abstract}

Keywords: brand attachment, brand-self connection, behavioral loyalty, attitudinal loyalty, affective loyalty

\section{Introduction}

The increasing competition in the market has resulted in marketers' shift toward the application of some strategies to attract competitive advantage in marketplace. Many organizations have already realized the value of their current customers and try to find ways of improving their lasting loyalty (Rajumesh, 2014). The creation of customer loyalty - esp. among banking customers - is a concept that has been more and more attended to by today's enterprises because such a form of loyalty is one of the main components of banking success. Apart from exclusively state firms, not a single business can survive without having loyal customers. Moreover, the fact is that customer expectations are constantly rising and banks are obliged to go beyond the basic needs of customers, try to accommodate such expectations; therefore, they shift their focus from simply satisfying customers to creating loyalty through the establishment of long-term, mutual, and mutually profitable connections (Dick \& Basu, 1994).

Brands play vital roles as one of the intangible assets of organizations. In this regard, brands are considered as the link between consumers and companies; it is possible that consumers establish attachment and interest in certain brands (Rajumesh, 2014). Brand attachment is something far more than a mere attitudinal construct; such a concept is able to explain more complicated behaviors of consumers in relation to brand commitment. Hence, we can say that brand attachment is one of the features of consumer-brand relationship that ends in "automatic preservation of their thoughts and feelings about the brand" (Park et al., 2006).

It has been observed in recent studies that affective reactions to brands can predict brand loyalty. Empirical research suggests that the affective components of brands are determining in purchase and loyalty due to the direct effect that brand attachment has on brand loyalty (Tsiotsou, 2010).

Brand attachment is a deep emotional connection between the consumer and brand and an essential part of successful brand management (Fornier, 1998). The creation of this emotional connection between consumers and brand is one of the goals of every business attempt. Strong connections cause the achievement of positive results 
such as loyalty and premium price (Malar et al., 2011; Thomson et al., 2005; Park et al., 2010). As Grisaf \& Guein (2011) have found out, when sustainable emotional links between the consumer and brand emerge, companies achieve financial profit and their repeat purchase profit caused by such links is less prone to switching.

Understanding how attachment is created or empowered can be the key to the achievement of successful marketing relations (Thomspon, 2006). Besides, some positive consequences such as the increase in defending reactions of consumers against negative information (Alhavalie et al., 2001) and the minimization of consumer desertion (Liljander \& Starduic, 1995) are recognized as the results of stronger attachment.

This study seeks to examine the role of brand attachment on financial service loyalty. In the following pages, the factors that influence or are under the influence of brand attachment, brand attachment dimensions, seven dimensions of loyalty and the interaction between them will be examined and finally the results will be discussed.

\section{Literature Review}

\subsection{Brand Attachment}

In social psychology theory, attachment is an emotional related bond between a person and a particular object in marketing theory, consumers can also create and maintain emotion laden bond with brands. Hence, brand attachment connects the consumer with particular brand and engages with that brand feeling. These brand feelings consists affection, passion, and connection. Attachment is a bond which is created by an individual from their childhood with their parents; later in their life, it is developed with other "objects" such as brands. A person having attached relationship passion normally believes that the relationship partners as distinguishable and irreplaceable element (Rajumesh, 2014). Brand attachment can be concerned as the final destination of consumer-brand relationships (Shestakov, 2012).

Two factors indicate brand attachment: 1) the extent of brand-self connection, and 2) automaticity of thoughts and emotions toward the brand. Brand-self connection and emotional automaticity toward the brand are highly correlated; in other words, the latter is the result of the former (Park et al., 2006). The early studies by Thomson et al. (2005) indicated that the emotional attachment to a brand implied a link between the consumer and a certain brand, and the link itself included feelings toward the brand. In later studies, not only did attachment have emotional links, but more cognitive links were added to it. Personalized experiences and routine memories of a brand would create some rich cognitive schemes in which brands are connected to personalized elements by some links (Park et al., 2006).

Park and colleagues (2010) defined brand attachment as the strength of the link connecting the self to the brand. They express that brand-self connection and brand prominence are two vital factors emergence of which point to the conceptual characteristics of brand attachment. When consumers feel a mutual understanding toward a brand, they try to make them consistent with their own images. The degree of the ease and frequency of brand-related thoughts retrieval is defined as brand prominence (Park et al., 2010).

Based by Researches, many factors affected from B.A:

1). Self-congruence. It is defined as the consistency between the consumers' self and brand image (Sirgy, 1982). According to the studies by Malar and colleagues (2011), self-congruence is a fundamental concept that has an important role in the creation and empowerment of emotional attachment to the brand.

2). Consumer satisfaction. Carol and colleagues (2006) point out that when consumers show more satisfaction from and love toward a brand, they would be more loyal and would engage in positive word of mouth. When satisfaction is high, the degree of emotional attachment in positive affective circumstances would be much higher (Orth et al., 2010).

3). Brand familiarity. It consists of the sum of experiences that a consumer has about a brand in direct or indirect ways (Kent \& Allen, 1994). Hazan \& Shaver (1994) believe that familiarity and responsiveness are in relationship with the selection of the type of attachment. They argue that these two constructs are the basics of attachment because both are determining and influential in preferences and the process of attachment selection.

4). Brand responsiveness. When a brand enhances the feeling of independence and relevance in the consumer and does not suppress their feeling of capability, the possibility of the consumer's deep attachment to the brand will rise (La Guardia \& Partick, 2008).

Also, seven Factors affected on B.A indicated in research:

1). Brand loyalty. In Thomson and colleagues' opinion (2005), it can be expected that deep attachments toward 
brands are effective on brand loyalty and can give rise to negative evaluation of rivals.

2). Maximum premium achievement. The creation of attachment between the consumer and brand is one of the main goals of an organization. The reason is that strong links result in positive outcomes such as loyalty and premium price achievement (Malar et al., 2011; Thomson et al., 2005; Park et al., 2010).

3). Brand commitment and financial sacrifice willingness. The emotional attachment of consumers to a certain brand may be able to predict their commitment to the brand (e.g., loyalty) and their willingness to make financial sacrifices in order to possess that brand. Commitment has been defined as the extent of the long-term view of an individual toward a relationship and the tendency to stay in relationship even in difficulties (Thomson et al., 2005). Park et al. (2006) consider brand commitment as an outcome of attachment.

4). Affective involvement. Just like commitment, it is derived from brand attachment. Those consumers who are attached to a brand may become involved in it. Therefore, involvement in those brands to which consumers are more attached should be higher (Thomson et al., 2004).

5). Consumer's behavior prediction and purchase share. From a managerial standpoint, brand attachment is more accurately capable of predicting the intentions related to the emergence of those behaviors that consumer significant amounts of consumer resources (time, money, and reputation). Park \& MacInnis (2010) believe that such effects can be observed in terms of consumer behavior, brand purchase share, and brand need share.

6). Purchase intention. The feeling of an emotional bond causes the consumer to be attached to the brand affectively and consider it as important. Such a behavior is in turn effective in their purchase intentions (Chieh-Peng et al., 2011).

7). Resource allocation and relationship continuance. The extent of emotional attachment to anything can be related to the allocation of resources to that thing. That is, there exists a willingness to leave short-term profit in order to promote the current relationship (Thomson et al., 2005; Shestakov, 2012).

In the following model, the dimensions of brand attachment and the factors that influence or are influenced by it are presented.

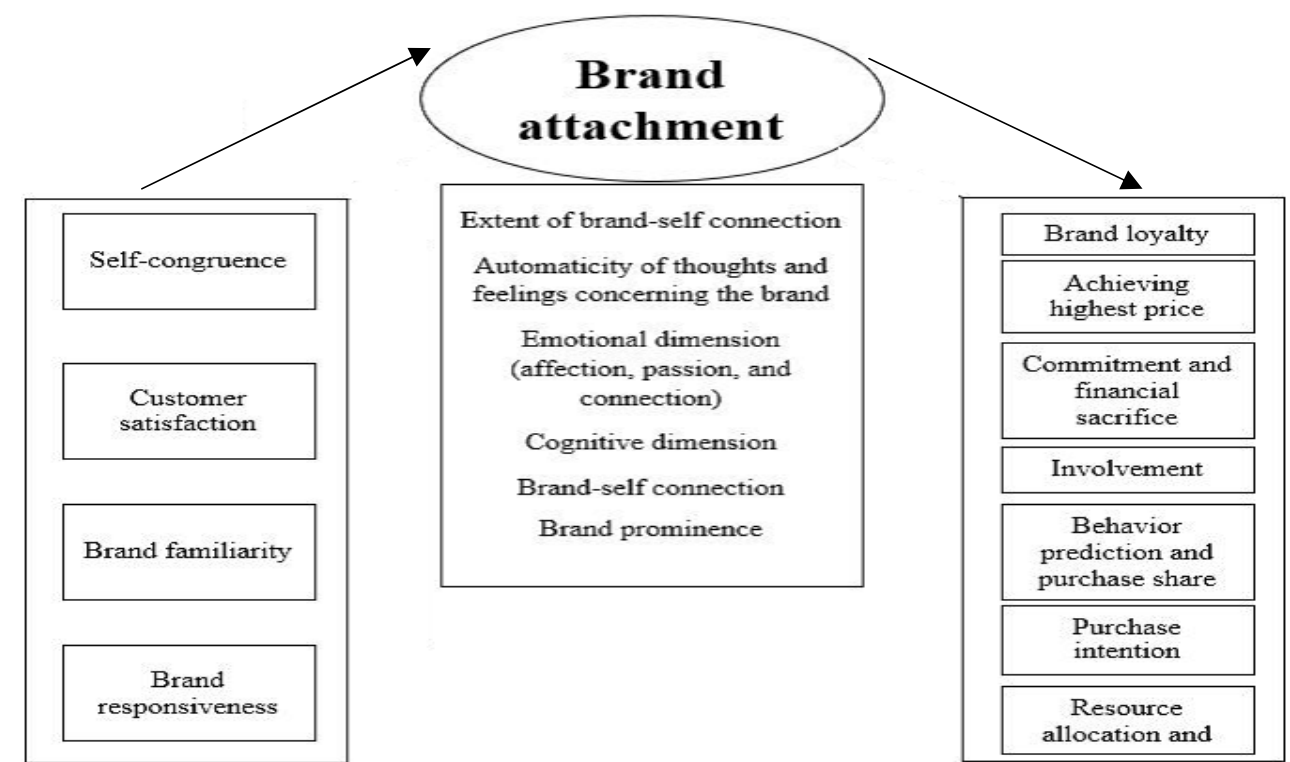

Figure 1. Conceptual model of brand attachment (dimensions, influential and influenced factors) Taghipourian and Mahsayegh Bakhsh, 2015

\subsection{Service Loyalty}

Although loyalty studies date back to around a hundred years ago, customer loyalty is still regarded as a very novel research area (Copeland, 1923). Today, the importance of marketing managers' awareness of influencing customer loyalty is constancy increasing (Reichheld \& Sasser, 1990). With the constant increase of competition, the maintenance and increase of customers are turned into the first goal of many companies (Chegini, 2010). Loyal customers can be considered as the key to succeeding in many business attempts in service sector (Tripathi, 
2009). In the following figure, the dimensions of loyalty are diagramed.

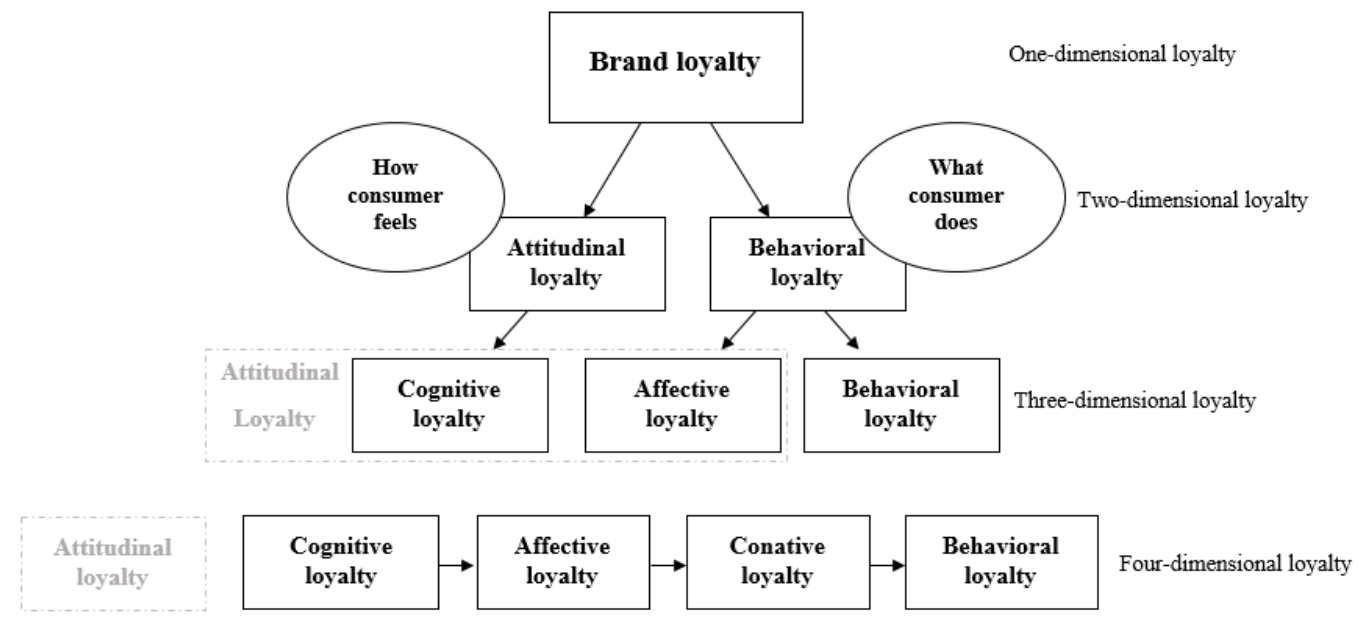

Figure 2. Loyalty dimensions, Taghipourian and Mashayekh Bakhsh, 2015

In this figure, the different conceptualizations of the dimensions of loyalty are provided. The first level indicates the one-dimensional approach created by the earlier researchers such as Cunningham (1956) and Farley (1964). Day (1969) was the first researcher who introduced the dimension of attitude in order to complement the behavioral aspect of loyalty, which is observable at the second level of the Figure 2. Worthington (2009) divided the attitudinal dimension into cognitive loyalty and affective loyalty, which is displayed in Figure 2 as the three-dimensional loyalty. This approach was supported by Dick \& Basu 91994) and Oliver (1997). Attitudinal loyalty is shaded gray because it is not regarded as a part of this level's conceptualization; rather, it stays in margin so that it could be included as a dimension of a multi-dimensional approach to loyalty. The conceptualization introduced by Oliver (1999) is adopted to be at the fourth level of the Figure, which includes four stages of loyalty.

Table 1. Stages of Loyalty and their vulnerabilities, from Oliver (1999)

\begin{tabular}{lll}
\hline Stage & Characteristics & Vlunerablities \\
\hline Cognitive & Realization of superior qualities and features & Superficial, weak loyalty \\
$\downarrow$ & Creation of attachment and attitudes toward the brand & Prone to switching \\
Affective & & \\
$\downarrow$ & Commitment or plan to repeat purchase & Intentions may never be fulfilled \\
Conative & & \\
$\downarrow$ & High willingness to act & May weaken performance \\
Active (behavioral) & & \\
\hline
\end{tabular}

Besides the previous conceptualizations of the dimensions of loyalty, the multi-dimensional brand loyalty includes commitment and trust that, in several researchers' view, must be among the dimension of loyalty (e.g., Sudhahar et al., 2006; Morgan \& Hunt, 1995; Bendapudi \& Berry, 1997; Baloglu, 2002; Alhabeeb, 2007).

\section{Theoretical Model}

In accordance with the theory of consumer-brand relationships, brand attachment refers to the high-level relationship between the consumer and the brand that is able to provide a better prediction of loyal behavior of the consumer (Park et al., 2006). Although brand attachment is directly and positively effective on brand loyalty, product attachment would indirectly drive brand loyalty through the moderating effects of brand attachment (Pedeliento et al., 2015). Therefore:

\section{H: Brand attachment is positively effective on banking service loyalty.}

Rajumesh (2014) studied the effect of trust and attachment on behavioral loyalty and attitudinal loyalty with the moderating roles of age, sex, and interest in these relationships. The results of the study indicated that brand attachment influences brand behavioral and attitudinal dimensions of loyalty. The next hypothesis would be: 


\section{H1. Brand-self connection is positively effective on banking service loyalty.}

\section{H2. Brand prominence is positively effective on banking service loyalty.}

Tsiotsou (2010) in a study on the effects of brand attachment and trust on brand loyalty based on a relational perspective states that affective responses to brands can predict brand loyalty. Empirical studies show that the affective brand components are determining in purchase and attitudinal loyalty because attachment directly affects loyalty. Chaudhuri \& Holbrook (2001) state in their study that affective responses to brands can be the antecedents of brand loyalty. They found out that brand attachment is positively in relationship with loyalty. Therefore, the next hypotheses are as follows:

\section{H3. Brand-self connection is positively effective on banking service loyalty.}

\section{H4. Brand prominence is positively effective on banking service loyalty.}

Cognitive loyalty constitutes the first stage of loyalty. This dimension emerges out of background/concrete knowledge or experience-based recent information (Oliver, 1999). Individuals get cognitively loyal through making comparisons between their preferred product and alternatives, which is based on their past knowledge and observations that are related to the product, its properties, performance, or such a process can even be through recent experiences. Many studies in the field of marketing and consumer behavior have shown that cognitive loyalty basically takes in the perceived value from the functional/psychological aspects and quality (Oliver, 1999). Today's researchers emphasize the psychological element, which covers both attitudinal and emotional concepts. In such approaches, customers are loyal either behaviorally or attitudinally. The former is loyal without having any emotional bonds with the brand while the latter feels a kind of emotional attachment to the brand inside (Oliver, 1999; Jacoby \& Kyner, 1973; Reichheld, 2003). Thus, we can hypothesize that:

\section{H5. Brand-self connection is positively effective on banking service cognitive loyalty.}

\section{H6. Brand prominence is positively effective on banking service cognitive loyalty.}

Oliver (1999) states that conative loyalty appears after the repeated emergence of positive feelings toward a brand. Conation is defined as a type of commitment or plan to repeat purchase from a given brand. Hence, the next hypotheses would be:

\section{H7. Brand-self connection is positively effective on banking service conative loyalty.}

\section{H8. Brand prominence is positively effective on banking service conative loyalty.}

Reichheld (2003) puts the emphasis on the psychological element, which deals with both attitudinal and emotional concepts of loyalty. In such approaches, customers may be behaviorally or emotionally loyal. Contrary to emotionally loyal customers who feel some sorts of emotional attachment to the brand, behaviorally loyal customers do not show any emotional bonds with it. Worthington and colleagues (2009) have defined affective loyalty as an "affective commitment" that a customer shows toward a brand, which involves positive feelings toward it and commitment to buy it again. As a result, we can hypothesize that:

\section{H9. Brand-self connection is positively effective on banking service affective loyalty.}

\section{H10. Brand prominence is positively effective on banking service affective loyalty.}

Esch et al. (2006) have studied on the effect of trust on brand attachment. They have reported significantly positive results, even more significant than that of satisfaction. They argue that brand trust has a positive relationship with brand attachment. Thus:

\section{H11. Brand-self connection is positively effective on customer's trust in banking services.}

\section{H12. Brand prominence is positively effective on customer's trust in banking services.}

In the study of Park et al. (2006), it has been mentioned that brand attachment is something more than a merely attitudinal construct. Rather, such a concept is capable of explaining more complicated behaviors of the consumer regarding brand commitment. They consider commitment as a consequence of attachment. Brand attachment reflects a psychological state of the consumer (strong self-brand connection and automatic retrieval of thoughts and feelings) while commitment reflects a tendency to keep on connecting with the brand. Attachment leads to commitment, but the reverse direction is not possible. As a result, we can hypothesize that:

H13. Brand-self connection is positively effective on customer's commitment-based loyalty to banking services.

H14. Brand prominence is positively effective on customer's commitment-based loyalty to banking services. 


\section{Methodology}

In order to collect the study data, two questionnaires of brand attachment and customer loyalty were utilized. The part related to brand attachment were adopted from Park et al. (2010), which included 10 questions with two items (brand-self connection, brand prominence). Loyalty part was adopted from Sudhahar (2006), which was comprised of 27 questions in seven items (behavioral, attitudinal, cognitive, conative, affective, customer trust, and customer commitment).

The study population consists of the real customers of private banks, here Bank Mellat as one of the biggest Iranian banks and Islamic countries. Out of 430 distributed questionnaires, 400 were usable for the purposes of data analysis.

In the study sample, more than $62 \%$ were women, $71 \%$ of the total samples were single, B.A. holders were $45.5 \%$, and $89.5 \%$ had visited the bank more than once.

In order to assess the validity of the instruments, confirmatory factor analysis via LISREL was used. Reliability of the instruments was calculated by Cronbach's alpha. Table 2 showed the results.

Table 2. Validity (CFA) and reliability (Cronbach's) results

\begin{tabular}{|c|c|c|c|c|}
\hline Construct & Dimension & Item & $\begin{array}{l}\text { Factor } \\
\text { loading }\end{array}$ & $\begin{array}{l}\text { Cronbach's } \\
\text { alpha }\end{array}$ \\
\hline \multirow{10}{*}{$\begin{array}{l}\text { Brand } \\
\text { attachment }\end{array}$} & \multirow{6}{*}{$\begin{array}{l}\text { Brand-self } \\
\text { connection }\end{array}$} & To what extent is (this bank) part of you and who you are? & 0.78 & \multirow{6}{*}{0.913} \\
\hline & & To what extent do you feel personally connected to (this bank)? & 0.82 & \\
\hline & & To what extent do you feel Emotionally bonded to (this bank)? & 0.83 & \\
\hline & & To what extent is (this bank) Part of you? & 0.82 & \\
\hline & & $\begin{array}{l}\text { To what extent does (this bank) say something to other people } \\
\text { about who you are? }\end{array}$ & 0.79 & \\
\hline & & $\begin{array}{l}\text { To what extent are your thoughts and feelings toward (this bank) } \\
\text { often automatic, coming to mind seemingly on their own? }\end{array}$ & 0.74 & \\
\hline & \multirow{4}{*}{$\begin{array}{l}\text { Brand } \\
\text { prominence }\end{array}$} & $\begin{array}{l}\text { To what extent do your thoughts And feelings toward (this bank) } \\
\text { come to your mind naturally and instantly? }\end{array}$ & 0.75 & \multirow{4}{*}{0.834} \\
\hline & & $\begin{array}{l}\text { To what extent do your thoughts and feelings toward (this bank) } \\
\text { come to mind so naturally and instantly that you don't have much } \\
\text { control over them? }\end{array}$ & 0.80 & \\
\hline & & $\begin{array}{l}\text { To what extent does the word (this bank) automatically evoke } \\
\text { many good thoughts about the past, present, and future? }\end{array}$ & 0.66 & \\
\hline & & To what extent to you have many thoughts about (this bank)? & 0.75 & \\
\hline \multirow{19}{*}{ Loyalty } & \multirow{4}{*}{ Behavioral } & I will transact with this bank again for future needs & 0.64 & \multirow{4}{*}{0.808} \\
\hline & & I will try the new services that are provided by this bank. & 0.72 & \\
\hline & & I will recommend other people to patronize to this bank & 0.76 & \\
\hline & & $\begin{array}{l}\text { I will say positive things to other people about the services } \\
\text { provided at this bank }\end{array}$ & 0.71 & \\
\hline & \multirow{3}{*}{ Attitudinal } & $\begin{array}{l}\text { I will continue to patronize this bank even if the service charges } \\
\text { are increased moderately }\end{array}$ & 0.57 & \multirow{3}{*}{0.709} \\
\hline & & I have strong preference to this bank & 0.68 & \\
\hline & & $\begin{array}{l}\text { I am likely to pay a little bit more for using the services of this } \\
\text { bank }\end{array}$ & 0.62 & \\
\hline & \multirow{5}{*}{ Cognitive } & To me, this bank would rank first among the other banks. & 0.68 & \multirow{5}{*}{0.837} \\
\hline & & I would patronize this bank for a long period of time & 0.69 & \\
\hline & & I will deal exclusively with this bank & 0.70 & \\
\hline & & I think of this bank as my bank & 0.70 & \\
\hline & & The bank I patronize reflect a lot about who I am & 0.65 & \\
\hline & \multirow{3}{*}{ Conative } & I have found this bank better than others & 0.77 & \multirow{3}{*}{0.798} \\
\hline & & I always find the terms of this bank are inferior & 0.74 & \\
\hline & & $\begin{array}{l}\text { Repeatedly, the performance of this bank is superior to that of } \\
\text { competitor's one }\end{array}$ & 0.75 & \\
\hline & \multirow{4}{*}{ Affective } & I dislike the bank terms & 0.81 & \multirow{4}{*}{0.781} \\
\hline & & I like the performances and services of the bank & 0.86 & \\
\hline & & I have a negative attitude toward this bank & 0.81 & \\
\hline & & I am satisfied with my decision to stay with this bank & 0.82 & \\
\hline
\end{tabular}




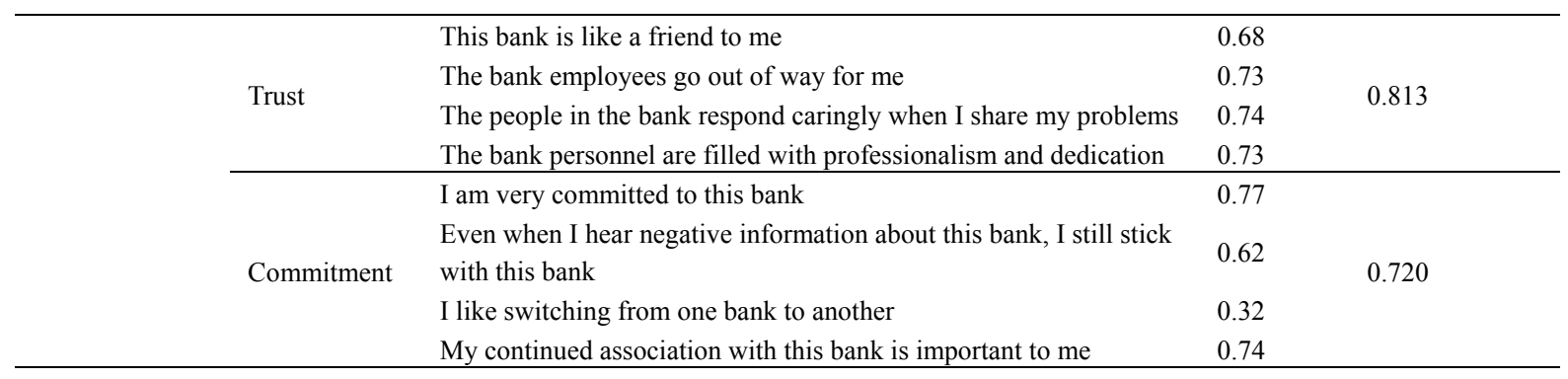

\section{Results}

The proposed hypotheses were tested using Structural Equation Modeling (SEM) via LISREL. To determine whether the hypotheses were supported, each structural path coefficient was examined with fit indices of the proposed model. The fit indices of model were shown in Table 2. Model displayed reasonably good fit to the data.

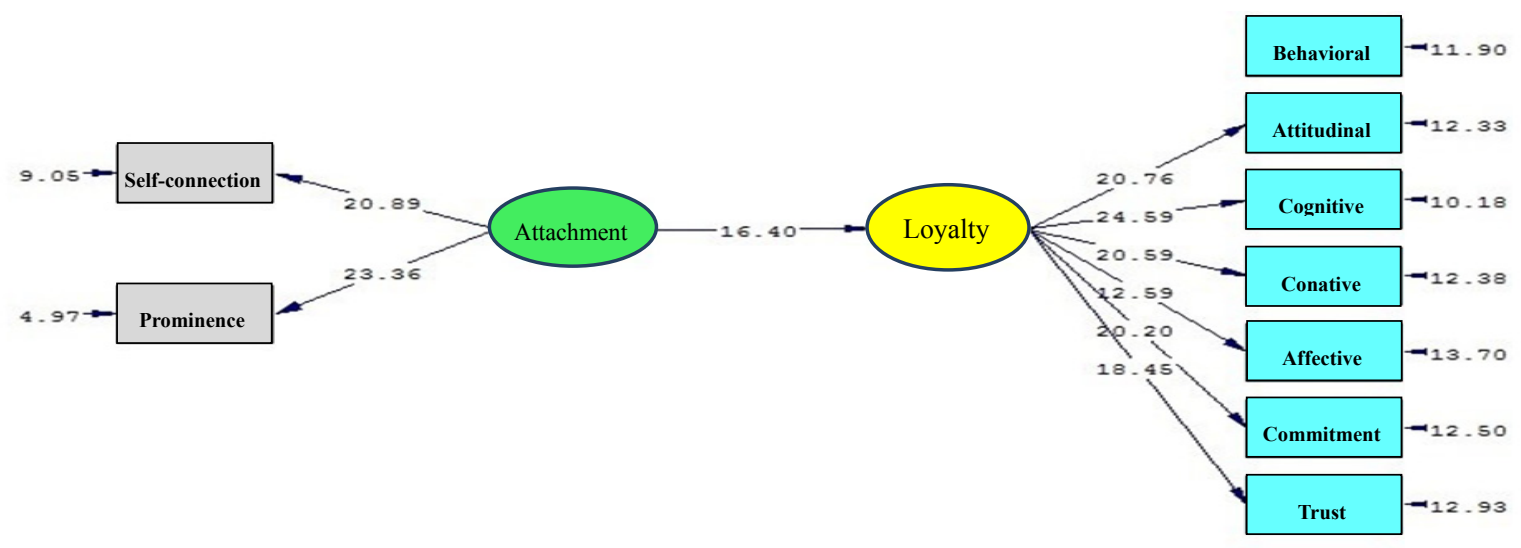

Figure 3. T-value and results of confirming the final model of brand attachment-loyalty relationship

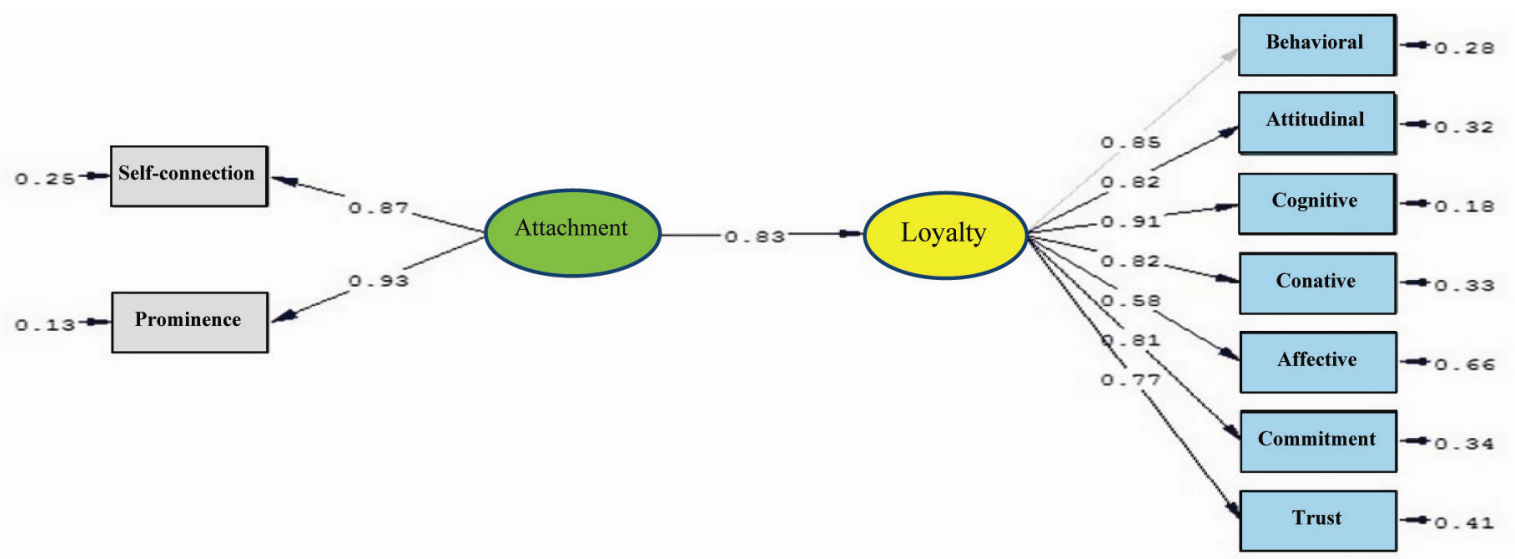

Figure 4. Results of confirming the final model of brand attachment-loyalty relationship

Figure 3 and Figure 4 indicated a general model of SEM. The result of T-TEST is 16.40; thus, brand attachment is effective on loyalty and also $\mathrm{R}$ value is 0.83 and positive, such an effect is positive. In addition, there is a positive effect on the dimensions of brand attachment - i.e., brand-self connection and brand prominence - and all dimensions of loyalty-i.e., behavioral, attitudinal, cognitive, conative, affective, commitment and trust. 
Table 3. Results of hypothesis testing

\begin{tabular}{llll}
\hline Hypothesized effect and sign & Estimate & t-value & Conclusion \\
\hline H1. Brand-self connection $\rightarrow$ behavioral loyalty & 0.37 & 4.06 & Supported \\
H2. Brand-self connection $\rightarrow$ attitudinal loyalty & 0.36 & 3.99 & Supported \\
H3. Brand-self connection $\rightarrow$ cognitive loyalty & 0.77 & 4.38 & Supported \\
H4. Brand-self connection $\rightarrow$ conative loyalty & 0.42 & 4.44 & Supported \\
H5. Brand-self connection $\rightarrow$ affective loyalty & 0.35 & 2.99 & Supported \\
H6. Brand-self connection $\rightarrow$ trust-based loyalty & 0.65 & 4.60 & Supported \\
H7. Brand-self connection $\rightarrow$ commitment-based loyalty & 0.75 & 4.02 & Supported \\
H8. Brand prominence $\rightarrow$ behavioral loyalty & 0.37 & 5.31 & Supported \\
H9. Brand prominence $\rightarrow$ attitudinal loyalty & 0.39 & 5.28 & Supported \\
H10. Brand prominence $\rightarrow$ cognitive loyalty & 0.65 & 5.51 & Supported \\
H11. Brand prominence $\rightarrow$ conative loyalty & 0.37 & 5.43 & Supported \\
H12. Brand prominence $\rightarrow$ affective loyalty & 0.62 & 3.22 & Supported \\
H13. Brand prominence $\rightarrow$ trust-based loyalty & 0.77 & 5.37 & Supported \\
H14. Brand prominence $\rightarrow$ commitment-based loyalty & 0.54 & 5.43 & Supported \\
\hline
\end{tabular}

Table 3 shown final results of hypothesis that the twofold dimensions of brand attachment are positively effective on sevenfold dimensions of service loyalty.

In Model, brand-self connection significantly and positively affects behavioral loyalty (H1), attitudinal loyalty (H2), cognitive loyalty (H3), conative loyalty (H4), affective loyalty (H5), trust-based loyalty (H6), commitment-based loyalty (H7). Similarly, brand prominence connection significantly and positively affects behavioral loyalty (H8), attitudinal loyalty (H9), cognitive loyalty (H10), conative loyalty (H11), affective loyalty (H12), trust-based loyalty (H13), commitment-based loyalty (H14). Therefore, all hypotheses were supported in the predicted directions.

\section{Conclusion}

Brand attachment is a deep emotional link between the consumer and brand, and is an essential constituent of successful brand management. The creation of this link between the consumer and the brand is among the goals of organizations because stronger links lead them to promising outcomes such as loyalty and achieving maximum price. In today's competitive world, customers are the cynosure of companies' attention and their loyalty is the precursor to competitive advantage. Creating loyalty in customers is a concept that is under the consideration of today's businesses more than ever.

The results of structural equations modeling in this study showed us that brand attachment had a positive and significant effect on the level of customers' loyalty to provided services. Further, there existed a positive relationship between brand-self connection and prominence as the dimensions of attachment and behavioral, attitudinal, cognitive, conative, affective, commitment-based and trust-based dimensions of loyalty. In this regard, brand-self connection had the biggest effect on cognitive, trust-based and commitment-based dimensions of loyalty. Brand prominence, on the other hand, was the most effective on affective, cognitive, and trust-based loyalty dimensions.

In this study, brand attachment was influential on service loyalty, which is consistent with the studies of Pedeliento et al. (2015), Yuksel et al. (2010), Jang et al. (2015).

Moreover, Shi Wen-hua et al. (2011) in a study on customer loyalty based on the cost of brand change and brand attachment, argue that brand attachment had moderating and significant effects on satisfaction and loyalty, even more significant that change costs. Among the three dimensions of brand attachment, brand-self relevance was the only dimension that did not have a significant moderating effect. The reason can be explained by the fact that the attachment of new customers may have not reached the state as close as that of those customers who regard their favorite brand as a continuation of their selves. Such results are different from the results of this study that confirmed the effect of self-relevance on service loyalty.

In this study, brand attachment was effective on behavioral and attitudinal loyalty, and this finding is consistent with the findings of Rajumesh (2014) and Tsiotsou (2010).

Furthermore, the effectiveness of brand attachment on conative loyalty was in line with the findings of Oliver (1999). Consistent with the findings of Worthington et al. (2009), the findings of this study showed that brand attachment was effective on affective loyalty.

Esch et al. (2006) studied on the effect of brand trust on brand attachment. They reported significantly positive 
results, even more significant than satisfaction. They state that brand trust has a positive relationship with brand attachment. Such results are in line with the results of this study that show the effect of brand attachment on trust-based loyalty.

Park et al. (2006) regard brand commitment as an outcome of brand attachment, which is in line with the results of this study that show the effect of brand attachment on commitment-based loyalty.

\section{Recommendations}

The Special offers for customers who repeat using the bank's services:

1) Offering new services to old customers, displaying customer citations in the bank because of the satisfying services offered by the bank.

2) Extracting positive experiences of customers and using them in advertisements, creating 24/7 communication channels with customers via applications such as SMS, internet bank etc.

3) Providing customers with true information regarding current and future services of the bank.

4) Providing customers with information regarding the place of the bank among rivals (winning the highest place from Euro Bank, being among the 10 best Iranian companies, such as winning two golden medals of the best popular brand in banking services and internet banking.

5) Meeting customer expectations in various areas, creating a strong public relations with customers regarding the bank's performance and its superiorities over other rivals, better relationship with the personnel and customers.

6) Providing solutions for solving customers' problems inside the bank building by the personnel and establishing more specialized and modern training courses for the personnel so that they can respond to customers faster and better.

7) Immediate response to rumors and negative information about the bank through public relations, intensifying switching costs by giving prizes to the customers.

8) Personalizing the bank's brand, reinforcing the personal links between the bank and customers, creating positive mental images about the bank's brand.

\section{Limitation and Future Research}

Some limitations to this study should be noted, and efforts to resolve them would serve as avenues for future counterfeiting research. The First present study has been completed in time period. As a result, customers' responses may change through time. In addition, public banks have been excluded from the study. Also based on the studies of Rajumesh (2014), we can consider demographic variables such as sex, age, and interest (affective involvement) as the moderators of the study variables. Further, it is recommended that a similar study be carried out in other financial organizations to provide a comparison between the achieved results.

\section{References}

Alhabeeb, M. J. (2007). On consumer trust and product loyalty. International Journal of Consumer Studies, 31(6), 609-612. http://dx.doi.org/10.1111/j.1470-6431.2007.00622.x

Baloglu, S. (2002). Dimensions of customer loyalty: separating the friends from the well wishers. Cornell Hotel and Restaurant Administration Quarterly, 43(1), 47-59. http://dx.doi.org/10.1016/S0010-8804(02)80008-8

Bendapudi, N., \& Berry, L. (1997). Customers' motivations for maintaining relationships with service providers. Journal of Retailing, 73(1), 15-37. http://dx.doi.org/10.1016/S0022-4359(97)90013-0

Chaudhuri, A., \& Holbrook, M. B. (2001). The chain of effects from brand trust and brand affect to brand perfomance: the role of brand loyalty. Journal of Marketing, 65(2), 81-94. http://dx.doi.org/10.1509/jmkg.65.2.81.18255

Chegini, M. G. (2010). Customer loyalty and value key dimensions interaction in organization. China-USA Business Review, 9(8), 8-14.

Copeland, M. T. (1923). Relation of Consumer's Buying Habits to Marketing Methods. Harvard Business Review, 1, 282-289.

Cunningham, R. M. (1956). Brand Loyalty—what, where, how much? Harward Business Review, 34, 116-128.

Day, G. S. (1969). A Two-Dimensional Concept of Brand Loyalty. Journal of Advertising Research, 9, 29-35.

Dick, A. S., \& Basu, K. (1994). Customer Loyalty: toward and integrated conceptual framework. Journal of the 
Academy of Marketing Science, 22(2), 99-113. http://dx.doi.org/10.1177/0092070394222001

Esch, F. R., Langner, T., Schmitt, B., \& Geus, P. (2006). Are brands forever? How brand knowledge and relationships affect current and future purchases. Journal of Product \& Brand Management, 15(2), 98-105. http://dx.doi.org/10.1108/10610420610658938

Farley, J. U. (1964). Why Does Brand Loyalty Vary Over Products? Journal of Marketing Research, 1(4), 9-14. http://dx.doi.org/10.2307/3150371

Fournier, S. (1998). Consumers and Their Brands: Developing Relationship Theory in Consumer Research. Journal of Consumer Research, 24(4), 343-373. http://dx.doi.org/10.1086/209515

Grisaffe, D. B., \& Nguyen, H. P. (2011). Antecedents of emotional attachment to brands. Journal of Business Research, 64, 1052-1059. http://dx.doi.org/10.1016/j.jbusres.2010.11.002

Hazan, C., \& Shaver, P. R. (1994). Attachment as an Organizational Framework for Research on Close Relationships. Psychological Inquiry, 5, 1-22. http://dx.doi.org/10.1207/s15327965pli0501_1

Jacoby, J., \& Kyner, D. B. (1973). Brand Loyalty Versus Repeat Purchasing Behaviour. Journal of Marketing Research, 10, 1-9. http://dx.doi.org/10.2307/3149402

Jang, Y. J., Kim, W. G., \& Lee, H. Y. (2015). Coffee shop consumers' emotional attachment and loyalty to green stores: The moderating role of green consciousness. International Journal of Hospitality Management, 44, 146-156. http://dx.doi.org/10.1016/j.ijhm.2014.10.001

Kent, R. J., \& Allen, C. T. (1994). Competitive Interference Effects in Consumer Memory for Advertising: The Role of Brand Familiarity. The Journal of Marketing, 58, 97-105. http://dx.doi.org/10.2307/1252313

Lin, C. P., Chen, S. C., Chiu, C. K., \& Lee, W. Y. (2011). Understanding Purchase Intention during Product-Harm Crises: Moderating Effects of Perceived Corporate Ability and Corporate Social Responsibility. Journal of Business Ethics, 102(3), 455-471. http://dx.doi.org/10.1007/s10551-011-0824-y

Malär, L. et al. (2011). Emotional Brand Attachment and Brand Personality: The Relative Importance of the Actual and the Ideal Self. Journal of Marketing, 75(4), 35-52. http://dx.doi.org/10.1509/jmkg.75.4.35

Morgan, R. M., \& Hunt, S. D. (1995). The Commitment-Trust Theory of Relationship marketing. Journal of Marketing, 58(3), 20-39. http://dx.doi.org/10.2307/1252308

Oliver R. L. (1999). Whence Customer Loyalty? Journal of Marketing, 63, 33-44. http://dx.doi.org/10.2307/1252099

Oliver, R. L. (1997). Satisfaction: A Behavioral Perspective on the Consumer. New York: McGraw-Hill,

Orth, U. R., Limon, Y., \& Rose, G. (2010). Store-evoked affect, personalities, and consumer emotional attachments to brands. Journal of Business Research, 63, 1202-1208. http://dx.doi.org/10.1016/j.jbusres.2009.10.018

Park, C. W., \& MacInnis, D. J. (2006). What's in and What's out: Questions on the Boundaries of the Attitude Construct. Journal of Consumer Research, 33, 16-18. http://dx.doi.org/10.1086/504122

Park, C. W., Maclinnis, D. J., Priester, J., Eisingerich, A. B., \& Iacobucci, D. (2010). Brand Attachment and Brand Attitiude Strength: Conceptual and Empirical Differentiation of Two Critical Brand Equity Drivers. Journal of Marketing. American Marketing association.

Pedeliento, G., Andreini, D., Bergamaschi, M., \& Salo, J. (2015). Brand and product attachment in an industrial context: The effects on brand loyalty. Industrial Marketing Management, 53, 194-206. http://dx.doi.org/10.1016/j.indmarman.2015.06.007

Rajumesh, S., \& Sritharan, V. (2014). Influence of moderating variables on attachment, brand trust and loyalty relationship. International Journal of Economics, Commerce and Management.

Reichheld, F. F. (2003). The One Number You Need to Grow. Harward Business Review, 81(12), 46-55.

Reichheld, F., \& Sasser, E. (1990). Zero Defections. Quality Comes to Service. Harvard Business Review, Sep.-Oct., pp. 105-111.

Shestakov, A. A. (2012). Moderating Role of Brand Attachment in Brand Crisis. To What Extent Does Brand Attachment Affect Purchase Intention in Brand Crisis: a Study Based on Apple's Crisis in China. Master Thesis.

Shi, W. H., Chen, J. J., \& Ma, J. M. (2011). A study of customer loyalty based on switching cost and brand attachment. The Journal of China Universities of Posts and Telecommunication, 18(suppl. 1), 136-141. 
http://dx.doi.org/10.1016/S1005-8885(10)60195-1

Sirgy, M. J. (1982). Self-Concept in Consumer Behavior: A Critical Review. Journal of Consumer Research, 9 , 287-300. http://dx.doi.org/10.1086/208924

Sudhahar, J. C., Israel, D., Britto A. P., \& Selvam, M. (2006). Service loyalty measurement scale: A reliability assessment. American Journal of Applied Sciences, 3(4), 1814-1818. http://dx.doi.org/10.3844/ajassp.2006.1814.1818

Taghipourian, M. J., \& Bakhsh, M. M. (2015). Brand Attachment: Affecting Factors and Consequences. International Journal of Engineering Research and Management (IJERM), 2.

Taghipourian, M. J., \& Bakhsh, M. M. (2015). Loyalty: From Single-Stage Loyalty to Four-Stage Loyalty. International Journal of New Technology and Research (IJNTR), 1, 48-51.

Thomson, M. (2006). Human Brands: Investigating Antecedents to Consumers' Strong Attachments to Celebrities. Journal of Marketing, 70, 104-119. http://dx.doi.org/10.1509/jmkg.70.3.104

Thomson, M. et al. (2005). The Ties That Bind: Measuring the Strength of Consumers' Emotional Attachments to Brands. Journal of Consumer Psychology, 15(1), 77-91 http://dx.doi.org/10.1207/s15327663jcp1501_10

Tripathi, S. (2009). An Analysis of Customer-pull Factors and the Process of Store Loyalty. Paradigm, 13(1), 91-103. http://dx.doi.org/10.1177/0971890720090112.

Tsiotsou, R. (2010). Brand loyalty through brand attachment and brand trust: a relational perspective. In Proceedings of 6th Thought Leaders. International Conference in Brand Management, April (pp. 18-20).

Worthington, S., Russell-Bennett, R., \& Hartel, C. E. J. (2009). A tridimensional approach for auditing brand loyalty. Journal of Brand Management, 17(4), 243-253. http://dx.doi.org/10.1057/bm.2009.24

Yuksel, A., Yuksel, F., \& Bilim, Y. (2010). Destination attachment: Effects on customer satisfaction and cognitive, affective and conative loyalty. Tourism Management, 31(2), 274-284. http://dx.doi.org/10.1016/j.tourman.2009.03.007

\section{Copyrights}

Copyright for this article is retained by the author(s), with first publication rights granted to the journal.

This is an open-access article distributed under the terms and conditions of the Creative Commons Attribution license (http://creativecommons.org/licenses/by/4.0/). 